\title{
HS-146, a novel phosphoinositide 3-kinase $\alpha$ inhibitor, induces the apoptosis and inhibits the metastatic ability of human breast cancer cells
}

\author{
OK HYEON KIM ${ }^{1,2^{*}}$, JU-HEE LEE $^{1 *}$, SHINMEE MAH ${ }^{3,4}$, SUNG YUN PARK ${ }^{1}$, \\ SUNGWOO HONG ${ }^{3,4}$ and SOON-SUN HONG
}

\begin{abstract}
${ }^{1}$ College of Korean Medicine, Dongguk University, Goyang, Gyeonggi 10326; ${ }^{2}$ Department of Anatomy and Cell Biology,
College of Medicine, Chung-Ang University, Seoul 06974; ${ }^{3}$ Center for Catalytic Hydrocarbon Functionalizations, Institute of Basic Science (IBS); ${ }^{4}$ Department of Chemistry, Korea Advanced Institute of Science and Technology (KAIST), Daejeon 34141; ${ }^{5}$ Department of Biomedical Sciences, College of Medicine, Inha University, Incheon 22332, Republic of Korea
\end{abstract}

Received August 28, 2019; Accepted February 21, 2020

DOI: $10.3892 /$ ijo.2020.5018

\begin{abstract}
The phosphoinositide 3-kinase (PI3K) signaling pathway plays an important role in human cancer as it regulates critical cellular functions, such as survival, proliferation and metabolism. In the present study, a novel PI3K $\alpha$ inhibitor (HS-146) was synthesized and its anticancer effects on MCF-7, MDA-MB-231, SKBR3 and BT-474 human breast cancer cell lines were confirmed. HS-146 was found to be most effective in inhibiting the proliferation of MCF-7 cells and in inducing cell cycle arrest in the G0/G1 phase by downregulating cyclin D1, cyclin E, cyclin-dependent kinase (Cdk)2 and Cdk4, and upregulating $\mathrm{p} 21^{\mathrm{Waf} 1 / \mathrm{Cip} 1}$ protein levels in this cell line. The induction of apoptosis by HS-146 was confirmed by DAPI staining and western blot analysis. Cell shrinkage and nuclear condensation, which are typical morphological markers of apoptosis, were increased by HS-146 in the MCF-7 cells in a concentration-dependent manner, and HS-146 also increased the protein expression levels of cleaved poly(ADP-ribose) polymerase (PARP) and decreased the protein expression levels of Mcl-1 and caspase-7. In addition, HS-146 effectively decreased the phosphorylation levels of downstream PI3K effectors, such as Akt, mammalian target of rapamycin
\end{abstract}

Correspondence to: Professor Soon-Sun Hong, Department of Biomedical Sciences, College of Medicine, Inha University, 366 Seohae-daero, Jung-gu, Incheon 22332, Republic of Korea E-mail: hongs@inha.ac.kr

Professor Sungwoo Hong, Department of Chemistry, Korea Advanced Institute of Science and Technology (KAIST), 291 Daehak-ro, Yuseong-gu, Daejeon 34141, Republic of Korea E-mail: hongorg@kaist.ac.kr

*Contributed equally

Key words: phosphoinositide 3-kinase a inhibitor, HS-146, proliferation, apoptosis, cell cycle, hypoxia, migration, invasion
(mTOR), glycogen synthase kinase $3 \beta$ (GSK3 $\beta$ ), p70S6K1 and eukaryotic translation initiation factor $4 \mathrm{E}$-binding protein 1 (4E-BP1). Hypoxia-inducible factor (HIF)-1 $\alpha$ and vascular endothelial growth factor (VEGF) expression were also suppressed by HS-146 under hypoxic conditions, and HS-146 inhibited the migration and invasion of MCF-7 cells in a concentration-dependent manner. On the whole, the findings of the present study suggest that HS-146, a novel PI3K $\alpha$ inhibitor, may be an effective novel therapeutic candidate that suppresses breast cancer proliferation and metastasis by inhibiting the PI3K/Akt/mTOR pathway.

\section{Introduction}

Breast cancer is one of the most common malignancies among women (1), and is the leading cause of female cancer-related mortality worldwide; it currently accounts for $>40,000$ deaths annually (2). The conventional therapies for breast cancer are surgery and chemotherapy $(3,4)$; however, these treatments have severe side-effects and cause patients physical and psychological distress. Therefore, the identification of a key therapeutic target molecule that can be utilized to eliminate the side-effects of current treatments is required.

A number of researchers have investigated various means of treating breast cancer, and the phosphoinositide 3-kinase (PI3K)/Akt/mammalian target of rapamycin (mTOR) pathway is one of the most frequent targets $(5,6)$. This pathway is known to regulate several cellular functions, such as cell proliferation, apoptosis, cell cycle and angiogenesis, and various metabolic functions, and has been demonstrated to play a key role in cancer progression (2). The PI3K pathway is commonly mutated in breast cancer via different mechanisms, which include i) the enhanced PI3K activity by mutation and/or amplification of PI3K encoding genes (e.g., PIK3CA, PIK3CB, or PIK3R1); ii) the excessive activation of receptor tyrosine kinases, such as human epidermal growth factor receptor 2 (HER2), epidermal growth factor receptor (EGFR), or insulin-like growth factor 1 receptor (IGF-1R); iii) the overexpression of the downstream effectors [e.g., Akt1, Akt2, or 3-phosphoinositide-dependent 
protein kinase-1 (PDK1)]; or iv) loss of function of tumor suppressor genes, such as phosphatase and tensin homolog (PTEN) and inositol polyphosphate 4-phosphatase type II (INPP4B) (7,8). In particular, the increased activity of the PI3K pathway has been linked with breast cancer tumorigenesis, drug resistance and clinical outcomes (8); thus, the inhibition of excessive PI3K pathway activation is viewed as a promising anticancer treatment strategy in breast cancer. The therapeutic efficacies of PI3K inhibitors, Akt inhibitors, mTOR inhibitors and dual PI $3 \mathrm{~K} / \mathrm{mTOR}$ inhibitors are currently being evaluated in clinical studies for the treatment of breast cancer and other types of cancer, including lung cancer, colorectal cancer and leukemia (9-12). Despite several clinical trial failures, everolimus (a selective mTOR inhibitor and rapamycin analogue) has been approved by the European Medicines Agency (EMA) and the United States Food and Drug Administration (US FDA) for the treatment of renal cancer, breast cancer and neuroendocrine tumors of gastrointestinal or lung origin (13). In addition, alpelisib (Piqray ${ }^{\mathrm{TM}}$, an orally available PI3K inhibitor) was recently approved for the treatment breast cancer by the FDA (14).

Thus, the authors focused on the development of potent $\mathrm{PI} 3 \mathrm{~K} \alpha$ inhibitors for the treatment of cancer, and identified a novel imidazopyridine scaffold and synthesized a novel imidazo[1,2-a]pyridine derivative, 2,4-difluoro-N-(5-(3(5-methyl-1,2,4-oxadiazol-3-yl) imidazo[1,2-a]pyridin-6-yl) pyridin-3-yl)benzenesulfonamide (HS-146) (15). The present study evaluated whether HS-146 exerts anticancer effects on breast cancer and investigated the molecular mechanisms of action of HS-146 using the MCF-7 human breast cancer cell line.

\section{Materials and methods}

Preparation of HS-146. The synthetic route for the preparation of HS-146 is presented in Fig. 1. The pyridyl sulfonamide group at the C6 position was installed by Suzuki coupling using the known intermediate oxadiazole ' $\mathrm{A}^{2}$ ' to provide ' $\mathrm{B}$ '. Treatment of ' $\mathrm{B}$ ' with 2,4-difluorobenzenesulfonyl chloride and pyridine then afforded HS-146.

Step 1: Synthesis of 5-(3-(5-methyl-1,2,4-oxadiazol-3-yl) imidazo[1,2-a]pyridin-6-yl)pyridin-3-amine. To a mixture of 3-[6-bromoimidazo[1,2-a]pyridin-3-yl)-5-methyl-1,2,4oxadiazole $(450 \mathrm{mg}, 1.8 \mathrm{mmol})$ were added 5-(4,4,5,5-tetramethyl-1,3,2-dioxaborolan-2-yl)pyridin-3-amine (470 mg, $2.1 \mathrm{mmol}), \mathrm{K}_{2} \mathrm{CO}_{3}(980 \mathrm{mg}, 7.1 \mathrm{mmol}$ ) and $\mathrm{Pd}(\mathrm{dppf})$ $\mathrm{Cl}_{2} \mathrm{CH}_{2} \mathrm{Cl}_{2}$ (73 mg, 5 mol\%). 1,4-Dioxane: $\mathrm{H}_{2} \mathrm{O}$ (=3:1, $4 \mathrm{ml}$ ) was added as a solvent, and the mixture was then heated to $100^{\circ} \mathrm{C}$ for $6 \mathrm{~h}$. The reaction mixture was cooled to room temperature and concentrated. Purification by flash column chromatography (DCM/MeOH=10:1) afforded 5-(3-(5-methyl-1,2,4-oxadiazol-3yl)imidazo[1,2-a]pyridin-6-yl)pyridin-3-amine (360 mg, 69\%).

Step 2: Synthesis of 2,4-difluoro-N-(5-(3-(5-methyl-1,2,4-oxadiazol-3-yl)imidazo[1,2-a]pyridin-6-yl)pyridin-3-yl)benzenes ulfonamide. To a solution of 5-(3-(5-methyl-1,2,4-oxadiazol3-yl)imidazo[1,2-a]pyridin-6-yl)pyridin-3-amine (24 mg, $0.082 \mathrm{mmol})$ and pyridine $(20 \mu \mathrm{l}, 0.24 \mathrm{mmol})$ in DCM $(5 \mathrm{ml})$ was added 2,4-difluorobenzenesulfonyl chloride (21 $\mu 1$,
$0.099 \mathrm{mmol})$. The resulting reaction mixture was stirred at room temperature for $24 \mathrm{~h}$ and then concentrated in vacuo. The residue was purified by flash column chromatography (DCM/MeOH=20:1) to yield 2,4-difluoro- $N$-(5-(3-(5-methyl1,2,4-oxadiazol-3-yl)imidazo[1,2-a]pyridin-6-yl)pyridin-3-yl) benzenesulfonamide (34 mg, 87\% yield). ${ }^{1} \mathrm{H}$ NMR(DMSO- $d_{6}$, $300 \mathrm{MHz}) \delta 2.73(\mathrm{~s}, 3 \mathrm{H}), 7.29(\mathrm{t}, 1 \mathrm{H}, \mathrm{J}=3.3 \mathrm{~Hz}), 7.55(\mathrm{t}, 1 \mathrm{H}$, $\mathrm{J}=2.9 \mathrm{~Hz}), 7.82(\mathrm{~m}, 2 \mathrm{H}), 7.96(\mathrm{~d}, 1 \mathrm{H}, \mathrm{J}=3.1 \mathrm{~Hz}), 8.05(\mathrm{dd}, 1 \mathrm{H}$, $\mathrm{J}=2.9,4.9 \mathrm{~Hz}), 8.38(\mathrm{~d}, 2 \mathrm{H}, \mathrm{J}=1.2 \mathrm{~Hz}), 8.65(\mathrm{~s}, 1 \mathrm{H}), 9.21(\mathrm{~s}, 1 \mathrm{H})$, $11.25(\mathrm{~s}, 1 \mathrm{H})$. HRMS (EI+) m/z calcd for $\mathrm{C}_{21} \mathrm{H}_{14} \mathrm{~F}_{2} \mathrm{~N}_{6} \mathrm{O}_{3} \mathrm{~S}$ $[\mathrm{M}+\mathrm{H}]^{+}, 469.0895$; found, 469.0907, HPLC purity $>99 \%$. For the in vitro experiments, HS-146 was prepared as a $10 \mathrm{mM}$ stock solution in dimethyl sulfoxide (DMSO, AppliChem), aliquoted and then stored at $-20^{\circ} \mathrm{C}$.

Docking simulation. The binding mode of HS-146 was determined using Discovery Studio 4.5 (www.3dsbiovia. com), and docking simulation was performed using the DS CHARMm-based CDOCKER docking algorithm. Ligand preparation was conducted with HS-146 under standard conditions ( $\mathrm{pH}$ 6.5-8.5). The X-ray structure (PDB 4YKN) was used as a protein target (16). For clarity, P-loop and a part of $\alpha$-helix are presented in the carbon alpha wire style.

High-throughput binding assay. To identify the selectivity of HS-146, the binding affinity of the compound against a panel of 70 kinases was tested in a high-throughput binding assay conducted by Eurofins DiscoverX (Fremont, CA 94538, www.discoverx.com) at a single $10 \mu \mathrm{M}$ concentration. In the assay, the compound exhibited a strong and competitive binding to PI3K $\alpha$ with a $K_{\mathrm{d}}$ value of $1.6 \mathrm{nM}$ (Fig. $2 \mathrm{~A}$ and Table SI).

Cell lines and cell culture. The human breast cancer cell lines MCF-7, MDA-MB-231, SKBR3, and BT-474 and the human breast epithelial cell line, MCF-10A, were used in the present study. MCF-7 and MDA-MB-231 cells were cultured in RPMI-1640 (Welgene). SKBR3 cells were cultured in DMEM medium (Welgene) supplemented with $10 \%$ fetal bovine serum (FBS, Welgene) and 1\% penicillin/streptomycin (Gibco; Thermo Fisher Scientific, Inc.), and BT-474 cells were maintained in Hybri-Care medium (American Type Culture Collection) supplemented with $10 \%$ FBS, and $1 \%$ penicillin/streptomycin. MCF-10A cells were grown in DMEM/F12 medium (Invitrogen; Thermo Fisher Scientific, Inc.) supplemented with EGF $20 \mathrm{ng} / \mathrm{ml}$ (PeproTech, Inc.), insulin $10 \mu \mathrm{g} / \mathrm{ml}$ (Sigma-Aldrich; Merck KGaA), hydrocortisone $500 \mathrm{ng} / \mathrm{ml}$ (Sigma-Aldrich; Merck KGaA), cholera toxin 100 ng/ml (Sigma-Aldrich; Merck KGaA), 5\% horse serum (Invitrogen; Thermo Fisher Scientific, Inc.) and 1\% penicillin/streptomycin. All cells were cultured in a humidified $5 \% \mathrm{CO}_{2}$ atmosphere at $37^{\circ} \mathrm{C}$.

Cell viability assay. An MTT (3-(4,5-dimethylthiazol-2yl)-2,5-diphenyltetrazolium bromide) assay was performed to evaluate the inhibitory effect of HS-146 on cell proliferation. In brief, the MCF-7, BT-474, SKBR3, MDA-MB-231, or MCF-10A cells were seeded at $1-10 \times 10^{3}$ cells per well in 96-well culture plates and allowed to adhere overnight. The media were then replaced with fresh medium containing the 


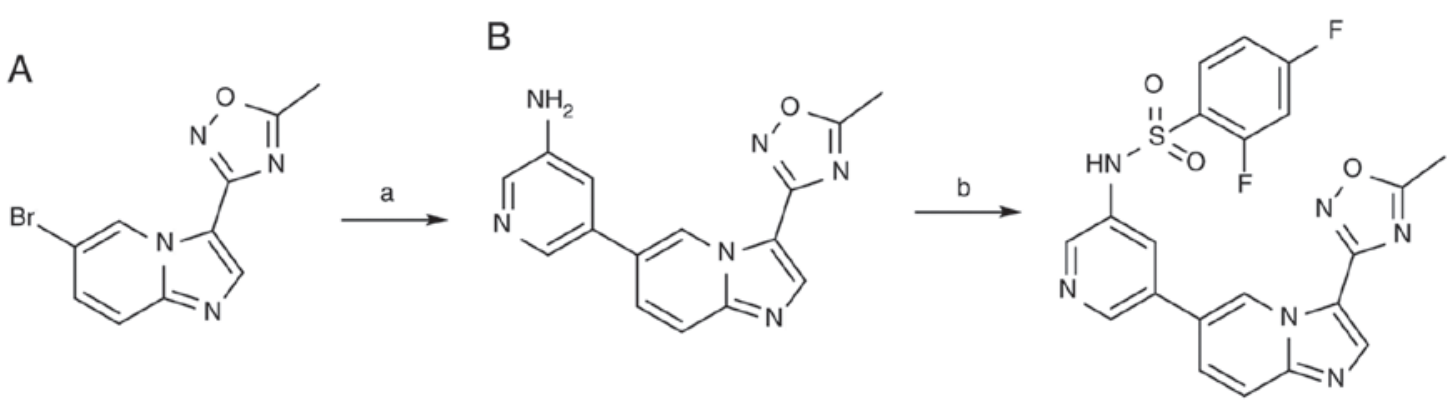

HS-146

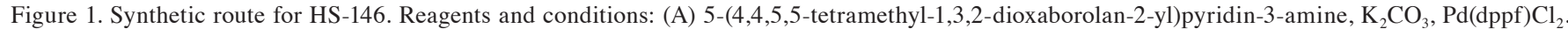
$\mathrm{CH}_{2} \mathrm{Cl}_{2}$, 1,4-dioxane, $\mathrm{H}_{2} \mathrm{O}, 100^{\circ} \mathrm{C}, 6 \mathrm{~h}$; (B) 2,4-difluorobenzenesulfonyl chloride, pyridine, DCM, room temperature, $24 \mathrm{~h}$.

A
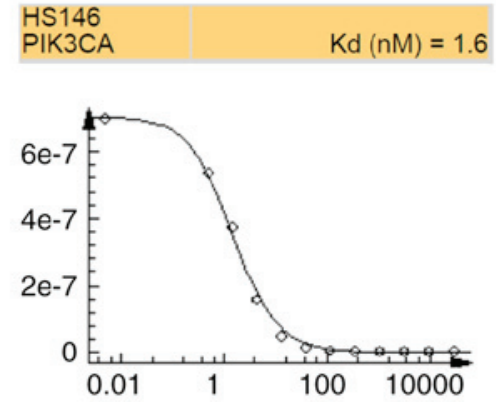

B

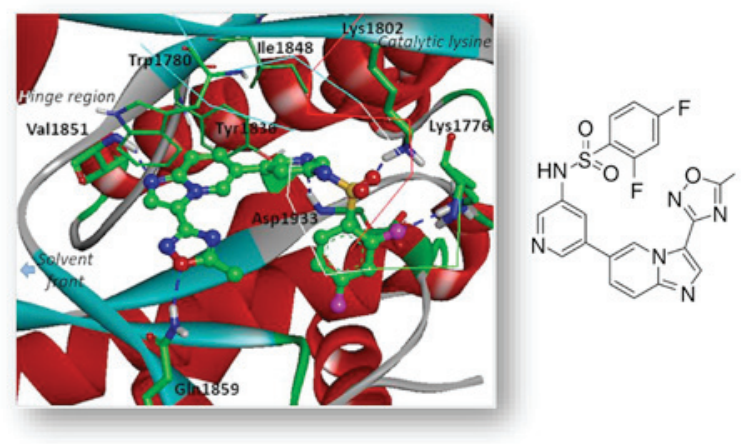

Figure 2. Characterization of HS-146. (A) Kd determination of HS-146 over PI3K $\alpha$. The amount of kinase (Signal; y-axis) is plotted against the corresponding compound concentration in $\mathrm{nM}$ in $\log 10$ scale (x-axis) (B) Calculated binding mode of HS-146 in the ATP binding pocket of PI3K $\alpha$ [PDB ID: 4YKN]. Hydrogen bonds are indicated by blue dotted lines.

vehicle (0.1\% DMSO as a control) or various concentrations $(0.1,0.5,1,5,10$, or $50 \mu \mathrm{M})$ of HS-146 and incubated for 24 , 48 , or $72 \mathrm{~h}$ at $37^{\circ} \mathrm{C}$, when $10 \mu 1 \mathrm{MTT}(0.2 \mathrm{mg} / \mathrm{ml}$ final concentration, Sigma-Aldrich; Merck KGaA) was added to each well and incubated for $3 \mathrm{~h}$ at $37^{\circ} \mathrm{C}$. Media containing MTT were then carefully removed and $100 \mu \mathrm{l}$ of DMSO (Junsei Chemical Co.) were added to each well and gently mixed for $30 \mathrm{~min}$. Well optical densities (OD) were then measured at $540 \mathrm{~nm}$ using a microplate reader (Tecan Group, Ltd.). The half maximal inhibitory concentration $\left(\mathrm{IC}_{50}\right)$ was calculated from the concentration-response curve obtained by plotting the cell survival vs. the drug concentration.

Cell cycle analysis. The MCF-7 cells were treated with vehicle or various concentrations $(0.1,1$, or $10 \mu \mathrm{M})$ of $\mathrm{HS}-146$ at $37^{\circ} \mathrm{C}$ for $24 \mathrm{~h}$, washed with phosphate-buffered saline (PBS), fixed in $70 \%$ ethanol overnight at $-20^{\circ} \mathrm{C}$, and stained with propidium iodide (PI)/RNase staining buffer (BD Biosciences) for $30 \mathrm{~min}$ at $37^{\circ} \mathrm{C}$ in the dark. Cell cycle distributions were determined using a FACSCalibur flow cytometer equipped with CellQuest software (BD Biosciences).

TUNEL assay. The apoptosis of MCF-7 cells was determined by terminal deoxynucleotidyl transferase (TdT)-mediated dUTP nick-end labeling (TUNEL) assay using a DeadEnd ${ }^{\mathrm{TM}}$ Colorimetric TUNEL System (Promega Corp.) according to the manufacturer's instructions. Briefly, the cells were fixed with 4\% paraformaldehyde in PBS for $25 \mathrm{~min}$ at room temperature and washed with PBS for $5 \mathrm{~min}$. The cells were permeabilized with $0.2 \%$ Triton X-100 solution in PBS for 5 min at room temperature. The cells were then incubated with equilibration buffer for $10 \mathrm{~min}$ at room temperature and incubated with rTdT reaction mixture for $1 \mathrm{~h}$ at $37^{\circ} \mathrm{C}$. After washing with 2X saline sodium citrate (2X SSC) solution for $15 \mathrm{~min}$ and PBS for $5 \mathrm{~min}$ at room temperature, the cells were incubated with DAB solution for $10 \mathrm{~min}$ in the dark. TUNEL-positive cells were observed under a microscope (Olympus Corp.).

Flow cytometric analysis of cell apoptosis. The apoptotic rate of the MCF-7 cells was determined by flow cytometry using a FITC Annexin V Apoptosis Detection kit (BD Biosciences). Briefly, collected cells were washed with cold PBS and incubated with binding buffer containing $5 \mu 1$ FITC Annexin V and $5 \mu \mathrm{lPI}$ for $15 \mathrm{~min}$ at room temperature in dark conditions. The stained cells were analyzed using a CytoFLEX flow cytometer equipped with CytExpert software (Beckman Coulter, Inc.).

Assessment of mitochondrial membrane potential. The MCF-7 cells were pre-treated with or without $5 \mu \mathrm{M}$ SC79 (Sigma-Aldrich; Merck KGaA, an Akt activator) for $1 \mathrm{~h}$, and then treated $10 \mu \mathrm{M}$ HS-146 for $24 \mathrm{~h}$. Cells were stained with $0.05 \mu \mathrm{g} / \mathrm{ml}$ of rhodamine 123 (a fluorescent mitochondrial dye) for $1 \mathrm{~h}$ at $37^{\circ} \mathrm{C}$, collected, and resuspended in PBS containing $1 \%$ FBS. Changes in mitochondrial membrane potential were monitored by measuring green fluorescence intensities using a CytoFLEX flow cytometer equipped with CytExpert software (Beckman Coulter, Inc.).

Western blot analysis. Cells were rinsed with ice-cold PBS and lysed using RIPA buffer (Thermo Fisher Scientific, Inc.) containing protease inhibitor cocktail (GenDEPOT) and 
phosphatase inhibitor cocktail (GenDEPOT). Total protein concentrations were measured using a BCA protein assay kit (Thermo Fisher Scientific, Inc.). Equal amounts of total protein $(30-50 \mu \mathrm{g}$ ) were then boiled in sample buffer (Bio-Rad Laboratories, Inc.), separated by 8-12\% SDS-PAGE, and transferred onto PVDF membranes (EMD Millipore). Membranes were blocked with PBS containing Tween-20 in 5\% non-fat milk for $1 \mathrm{~h}$ at room temperature, incubated with primary antibodies [1:1,000 v/v; cyclin D1 (sc-8396), cyclin E (sc-247), cyclin-dependent kinase (Cdk)2 (sc-6248), Cdk4 (sc-56277), p21 ${ }^{\text {Wafl/Cip1 }}$ (sc-6246) (all from Santa Cruz Biotechnology, Inc.), poly(ADP-ribose) polymerase (PARP; \#9542, Cell Signaling Technology, Inc.), Mcl-1 (sc-12756, Santa Cruz Biotechnology, Inc.), caspase-7 (\#12827), phospho-Akt (\#9271), total Akt (\#9272), phospho-mTOR (\#2971), total mTOR (\#2972), phospho-glycogen synthase kinase (GSK)3 $\beta$ (\#9323, Cell Signaling Technology), total GSK3 $\beta$ (\#9315, Cell Signaling Technology), phospho-p70S6K1 (\#9234, Cell Signaling Technology), phospho-eukaryotic translation initiation factor 4E-binding protein 1 (4E-BP1; \#2855) (all from Cell Signaling Technology, Inc.), hypoxia-inducible factor (HIF)-1a (610958, BD Biosciences), vascular endothelial growth factor (VEGF, sc-152, Santa Cruz Biotechnology, Inc.), vimentin (V2258, Sigma-Aldrich Merck KGaA), E-cadherin (\#3195, Cell Signaling Technology, Inc.) and $\beta$-actin (sc-47778, Santa Cruz Biotechnology, Inc.)] overnight at $4^{\circ} \mathrm{C}$ and then incubated with horseradish peroxidase (HRP)-conjugated goat anti-rabbit and goat anti-mouse IgG secondary antibodies $(1: 5,000 \mathrm{v} / \mathrm{v}$; \#7074, \#7076, Cell Signaling Technology, Inc.) for $1 \mathrm{~h}$ at room temperature. Signals were detected using Amersham ${ }^{\mathrm{TM}} \mathrm{ECL}^{\mathrm{TM}}$ Prime Western Blotting Detection Reagent (GE Healthcare), and densitometric analysis of the bands was performed using ImageJ 1.48v software (NIH).

4,6-Diamidio-2-phenylinodole (DAPI) staining. MCF-7 cells were plated onto cover glasses in RPMI-1640 medium and allowed to reach $70 \%$ confluence $(\sim 24 \mathrm{~h})$, fixed in ice-cold $4 \%$ paraformaldehyde, washed with PBS, and stained with $2 \mu \mathrm{g} / \mathrm{ml}$ DAPI (Sigma-Aldrich; Merck KGaA) for $20 \mathrm{~min}$ at $37^{\circ} \mathrm{C}$. Stained cells were observed under a fluorescence microscope (Nikon Corp.).

Immunofluorescence assay. MCF-7 cells grown on cover glasses were treated with the vehicle or with HS-146 $(10 \mu \mathrm{M})$ for $6 \mathrm{~h}$, washed with PBS ( $3 \times 5 \mathrm{~min})$, fixed with $4 \%$ paraformaldehyde for $10 \mathrm{~min}$ at $4^{\circ} \mathrm{C}$, permeabilized with $0.2 \%$ Triton X-100, and blocked with a 5\% BSA solution for $1 \mathrm{~h}$ at room temperature. Cells were then incubated with phospho-Akt antibody (rabbit polyclonal, 1:200, \#9271, Cell Signaling Technology) overnight at $4^{\circ} \mathrm{C}$ and then with Alexa Fluor 488-conjugated goat anti-rabbit IgG secondary antibody (1:500, \#A-11008, Thermo Fisher Scientific, Inc.) for $1 \mathrm{~h}$ at room temperature. After washing, the cover glasses were mounted on slide glasses using mounting medium containing DAPI (Vector Laboratories, Inc.). Images were acquired using a fluorescence microscope (Nikon ECLIPSE Ts2-FL; Nikon Corp.).

Enzyme-linked immunosorbent assay (ELISA). MCF-7 cells were seeded into 6 -well plates, pre-treated with the vehicle or various concentrations of HS-146 $(0.1-10 \mu \mathrm{M})$ for $1 \mathrm{~h}$ and then treated with $100 \mu \mathrm{M}$ cobalt(II) chloride $\left(\mathrm{CoCl}_{2}\right)$ for $24 \mathrm{~h}$ to generate hypoxic conditions. Culture media were then harvested and centrifuged at 1,593 $\mathrm{xg}$ for $5 \mathrm{~min}$. VEGF levels in supernatants were measured using a human VEGF ELISA kit (AbFrontier).

Wound healing migration assay. MCF-7 cells were seeded into 6 -well culture plates and cultured until $90 \%$ confluent. The cells were wounded with a razor blade, and injury lines were marked. After wounding, the detached cells were removed by washing with serum-free medium, and the plates were further incubated for $48 \mathrm{~h}$ in serum-free RPMI-1640 medium containing the vehicle or various concentrations of HS-146 $(0.1,1$ or $10 \mu \mathrm{M})$. The cells were then rinsed with serum-free medium and fixed in absolute methanol. The cell migratory behavior was observed under a phase contrast microscope (Olympus Corp.) and documented.

Transwell invasion assay. The membranes of the upper Transwell chamber were coated with $20 \mu 1$ Matrigel (Matrigel:RPMI medium, 1:2; BD Biosciences) and incubated for $2 \mathrm{~h}$ at $37^{\circ} \mathrm{C}$. $5 \times 10^{4}$ cells resuspended in serum-free medium were then seeded in the upper chambers containing the vehicle or various concentration of HS-146 $(0.1,1$, or $10 \mu \mathrm{M})$, and bottom chambers were filled with $750 \mu$ l RPMI-1640 containing 10\% FBS. After $72 \mathrm{~h}$, non-invasive cells on the upper membrane surfaces were removed by wiping with cotton swabs, and cells that invaded the membranes were fixed with methanol and stained with crystal violet solution (Sigma-Aldrich; Merck KGaA) for 10 min at room temperature. The membranes were then dried in air and the invading cells were observed under an optical microscope (CKX53; Olympus Corp.).

Statistical analysis. The results are presented as the means \pm standard deviations (SD). Statistical significances of group differences were analyzed by one-way ANOVA followed by Tukey's multiple comparison test in GraphPad PRISM 5.03 (GraphPad Software). $\mathrm{P}<0.05$ was considered to indicate a statistically significant difference.

\section{Results}

Binding mode. To obtain insight of the inhibitory mechanisms of HS-146, its binding mode in the ATP binding site of PI3K $\alpha$ was investigated. The lowest energy conformation of HS-146-PI3K $\alpha$ complex was calculated using Discovery Studio 4.5 (Fig. 2B). The imidazopyridine core was located in the adenine binding site in the ATP binding pocket and formed a hydrogen bond with the backbone amide proton of Val1851. In addition, the oxadiazole moiety attached at the $\mathrm{C} 3$ position of imiazo[1,2-a]pyridine appeared to form a hydrogen bond with the side-chain amide proton of Gln 1859 . The pyridine moiety was located at the ribose binding pocket and interacted with the aspartate backbone in DFG motif. The binding of HS-146 was further stabilized by hydrogen bond formation with the two lysine side chains: Lys1802 interacted with oxygen atom of sulfonamide linkage, and Lys1776 in the P-loop interacted with the fluorobenzene group of HS-146. HS-146 was bound 
A

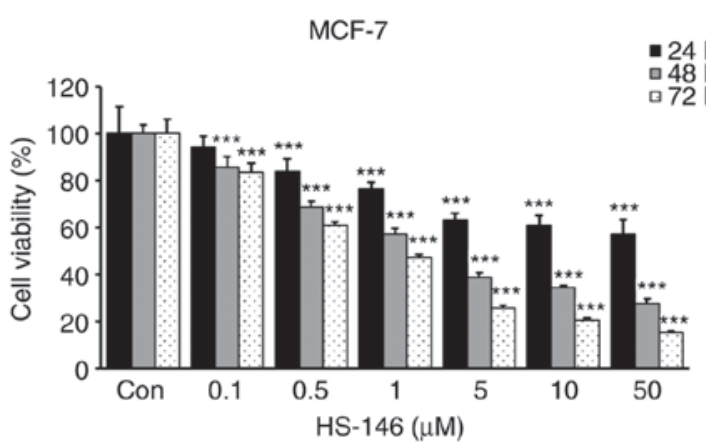

C

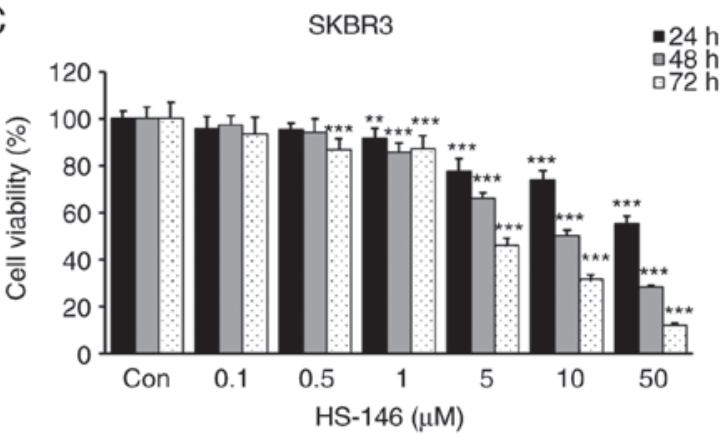

B

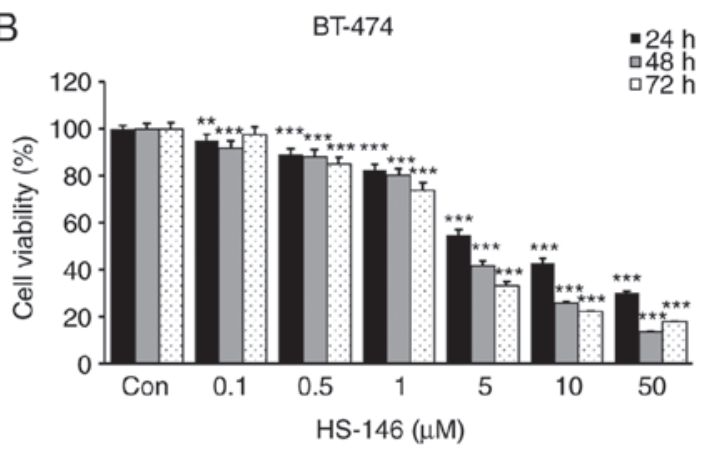

D

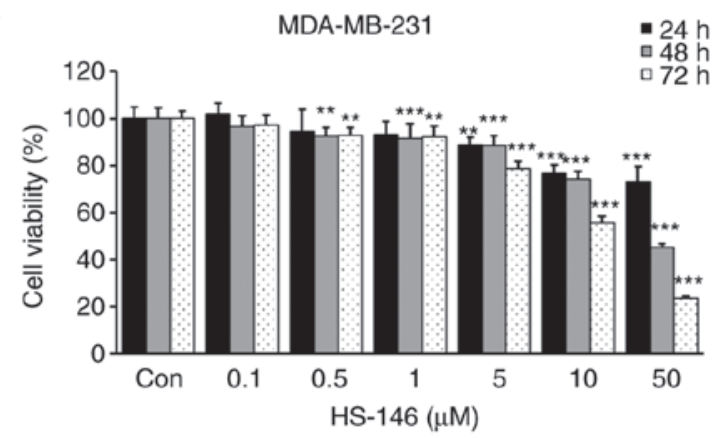

E

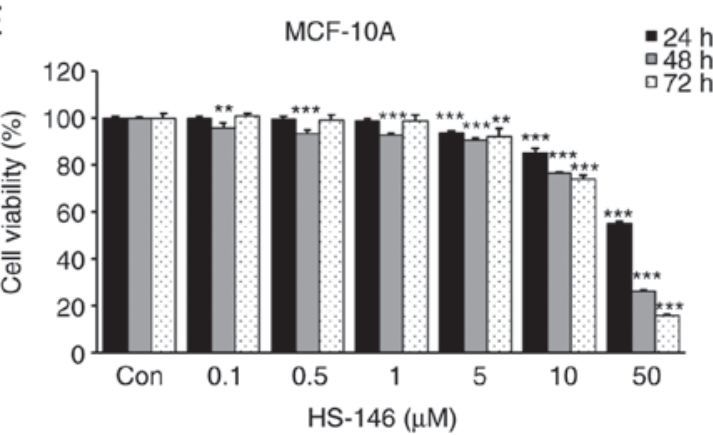

Figure 3. Effects of HS-146 on the proliferation of human breast cancer cell lines. (A) MCF-7, (B) BT-474, (C) SKBR3, (D) MDA-MB-231, and (E) MCF-10A cells were treated with the vehicle $(0.1 \%$ DMSO) or the indicated concentrations of HS-146 $(0.1-50 \mu \mathrm{M})$ for 24,48 , or $72 \mathrm{~h}$ and their viabilities were assessed by MTT assay. Results are presented as the means \pm SD. ${ }^{* *} \mathrm{P}<0.01$ and ${ }^{* * * *} \mathrm{P}<0.001$ vs. vehicle-treated control.

with moderate strength by van der Waals interactions with non-polar residues (e.g., Trp1780, Tyr1836 and Ile1848).

HS-146 is cytotoxic to human breast cancer cell lines. To evaluate the anticancer effect of HS-146, cytotoxicity tests were conducted on the MCF-7, BT-474, SKBR3 and MDA-MB-231 human breast cancer cell lines. The cells were treated with HS-146 at $0,0.1,0.5,1,5,10$, or $50 \mu \mathrm{M}$ for 24,48 , or $72 \mathrm{~h}$, and cell viabilities were assessed by an MTT assay. As a result, HS-146 decreased the viability of all 4 cell lines in a time- and concentration-dependent manner (Fig. 3). The $\mathrm{IC}_{50}$ values for HS-146 in the MCF-7, BT-474, SKBR3 and MDA-MB-231 cells were $2.5,4.1,10.6$ and $43.4 \mu \mathrm{M}$ at $48 \mathrm{~h}$, respectively. In addition, to determine whether HS-146 was cytotoxic to non-cancerous cells, the viability of the MCF-10A cells treated with HS-146 was measured. The result revealed that HS-146 was almost non-toxic up to $5 \mu \mathrm{M}$, and exerted minimal toxic effects on non-cancerous cells at $10 \mu \mathrm{M}$ (Fig. 3E). These results indicated that $\mathrm{HS}-146$ was most effective at inhibiting the proliferation of MCF-7 cells; thus, the MCF-7 cells were used in subsequent experiments.
$H S-146$ induces cell cycle arrest in the G0/G1 phase. To confirm whether the inhibition of cell proliferation by HS-146 was associated with cell cycle arrest, cell cycle distributions were evaluated by flow cytometry. The MCF-7 cells were treated with the vehicle or various concentrations of HS-146 $(0,0.1,1$, or $10 \mu \mathrm{M})$ for $24 \mathrm{~h}$ and then fixed and PI-stained. The DNA contents were then assessed by measuring the fluorescence intensities. As shown in Fig. 4, HS-146 increased the proportion of cells in the G0/G1 phase in a concentration-dependent manner by almost $20 \%$ from $63.93 \%$ (untreated controls) to $82.29 \%(10 \mu \mathrm{M})$, and decreased the percentages of cells in the $\mathrm{S}$ and $\mathrm{G} 2 / \mathrm{M}$ phases from $23.33 \%$ (control) to $5.64 \%(10 \mu \mathrm{M})$ and from $11.06 \%$ (control) to $6.87 \%(10 \mu \mathrm{M})$, respectively. These results indicated that HS-146 induced G0/G1 arrest and concomitantly reduced the percentages of cells in the $\mathrm{S}$ and $\mathrm{G} 2 / \mathrm{M}$ phases (Fig. 4A and B). In addition, the expression levels of the regulatory subunits, cyclin D1 and cyclin E, the cyclin-dependent kinases $(\mathrm{Cdks})$ partners of these cyclins, Cdk2 and Cdk4, and p21 $1^{\text {Waf1/Cip1 }}$, which are markers of cell cycle arrest (G1/S checkpoint effectors) were investigated by western blot analysis. Cyclin D1 has been reported to be 

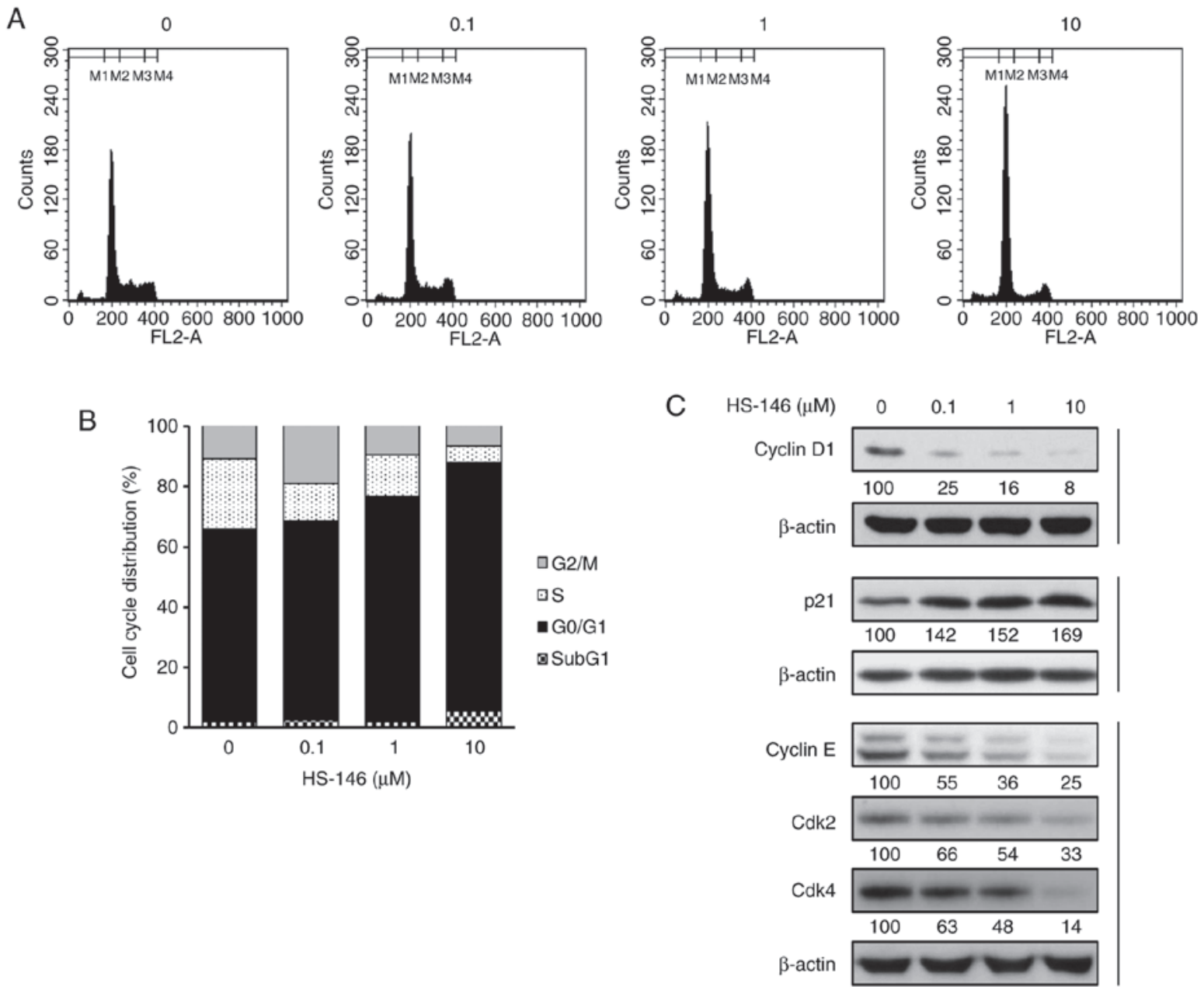

Figure 4. Effects of HS-146 on cell cycle distribution. (A) MCF-7 cells were treated with the indicated concentrations of HS-146 (0.1-10 $\mu \mathrm{M})$ for $24 \mathrm{~h}$ and then stained with PI. Cell cycle distributions were determined by flow cytometry. (B) Histogram presents cell cycle distributions as percentages. (C) The expression levels of the cell cycle-related proteins, cyclin D1, cyclin E, Cdk2, Cdk4 and p21 ${ }^{\text {Wafl/Cipl }}$, were assayed by western blot analysis. Numbers below the western blots represent the relative quantification of each band normalized to the loading control. Vertical black lines indicate western blot images on the same membrane.

a key requirement for cell proliferation in a number of types of cancers (17). HS-146 was found to downregulate cyclin D1, cyclin E, Cdk2 and Cdk4 expression in a concentration-dependent manner (Fig. 4C). p21 $1^{\text {Waf1/Cip1 }}$ is involved in the inhibition of cell cycle progression and in the induction of apoptosis (18). In the present study, HS-146 upregulated its expression in a concentration-dependent manner (Fig. 4C). These results indicated that the inhibition of cell proliferation by HS-146 was due to $\mathrm{G} 0 / \mathrm{G} 1$ cell cycle arrest.

HS-146 induces the apoptosis of MCF-7 cells. To explore the anticancer mechanisms of HS-146, the morphological changes of nuclei were investigated by DAPI and TUNEL staining. MCF-7 cells were treated with various concentrations of HS-146 $(0.1,1$, or $10 \mu \mathrm{M})$ and then compared with the untreated controls. As shown in Fig. 5A, HS-146 increased nuclear condensation and fragmentation in the MCF-7 cells in a concentration-dependent manner. These results were supported by the quantitative data of Annexin V-FITC/PI apoptosis assay (Fig. 5B and C). HS-146 significantly increased the proportion of the Annexin V-positive cells (early and late apoptotic cells) in a concentration-dependent manner ( $\mathrm{P}<0.001 \mathrm{vs}$. the vehicle-treated control). Furthermore, the expression levels of the apoptosis-related proteins, PARP, Mcl-1 and caspase-7, were examined by western blot analysis in the HS-146-treated cells. As shown in Fig. 5D, HS-146 increased the level of cleaved PARP (a pro-apoptotic marker) and suppressed the levels of Mcl-1 and caspase-7 in a concentration-dependent manner. These results suggested that the anticancer effects of HS-146 were due to the induction of apoptosis.

HS-146 inhibits the PI3K/Akt/mTOR pathway. To investigate the molecular mechanisms responsible for the anticancer activity of HS-146, the effects of HS-146 on the $\mathrm{PI} 3 \mathrm{~K} / \mathrm{Akt} / \mathrm{mTOR}$ signaling pathway were evaluated. MCF-7 cells were treated with various concentrations of HS-146 $(0.1,1$, or $10 \mu \mathrm{M})$ for $6 \mathrm{~h}$ and compared with the untreated controls. The expression levels of phosphorylated and total forms of Akt and of its downstream effectors, GSK3 $\beta$, mTOR, p70S6K1 and 4E-BP1, were assessed by western blot analysis. As shown in Fig. 6A, the protein expression levels of phospho-Akt, phospho-GSK3 $\beta$, phospho-p70S6K1 and phospho-4E-BP1 were effectively inhibited by HS-146 in a concentration-dependent manner. Treatment with HS-146 almost abrogated phosphorylated mTOR even at $0.1 \mu \mathrm{M}$. To determine whether HS-146 effectively inhibits Akt 
A
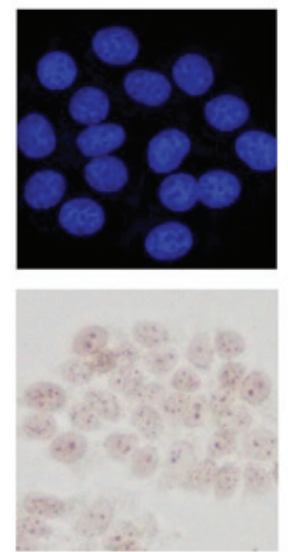

0.1
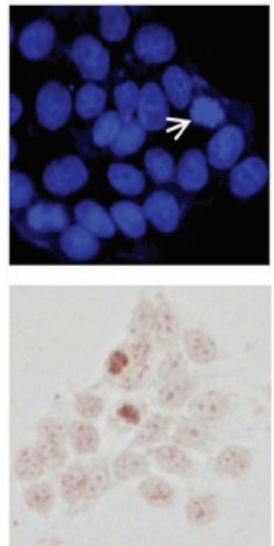

1
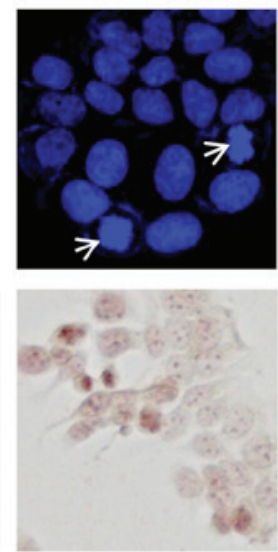

10
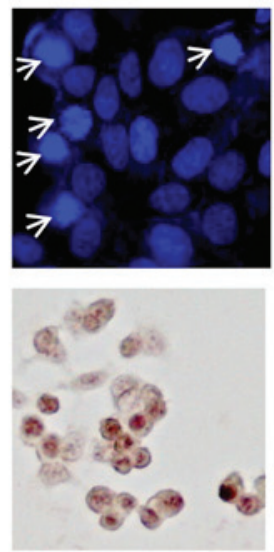

$\mathrm{B}$
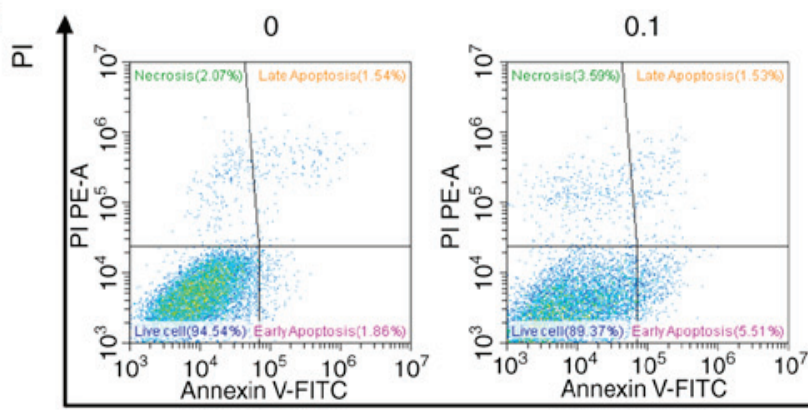

0.1

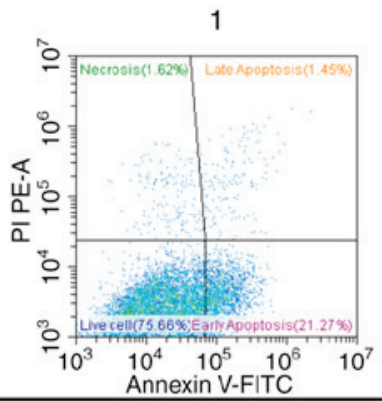

10

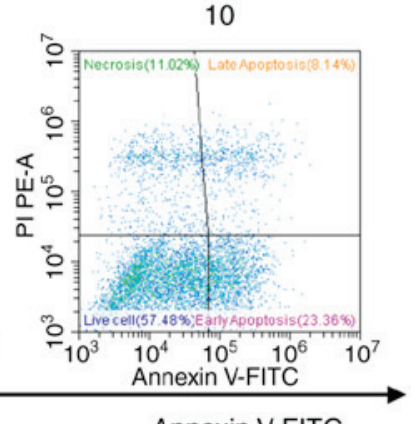

Annexin V-FITC
C

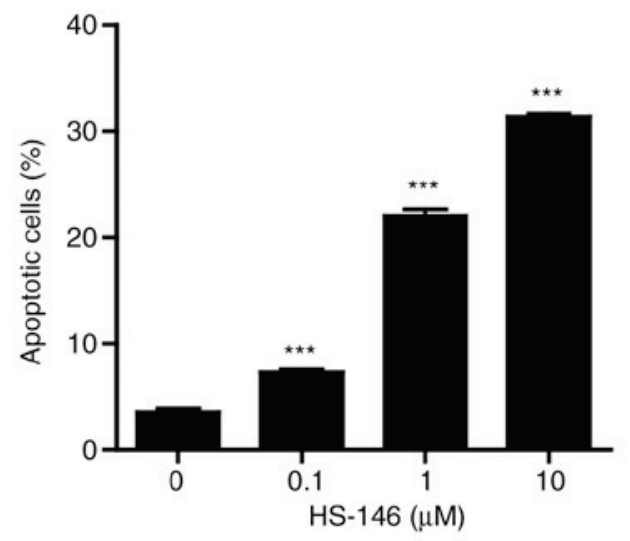

D

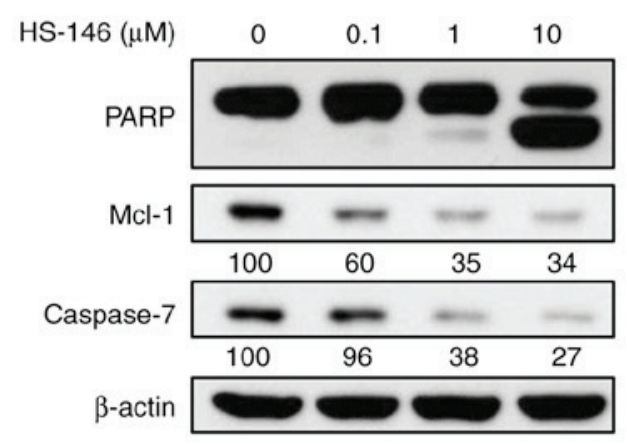

Figure 5. Effects of HS-146 on MCF-7 cell apoptosis. (A) DAPI (upper panels, x400 magnification) and TUNEL (lower panels, x200 magnification) staining of MCF-7 cells were treated with HS-146 (0-10 $\mu \mathrm{M})$ for $48 \mathrm{~h}$. White arrows indicate apoptotic cells with nuclear condensation (bright blue) representing apoptosis. (B) Representative plots obtained by Annexin V-FITC/PI flow cytometry analysis of HS-146-treated MCF-7 cells. (C) The percentages of apoptotic cells (early and late apoptotic cells). Results are presented as the means \pm SD. ${ }^{* * * *} \mathrm{P}<0.001$ vs. vehicle-treated control. (D) Expression levels of the apoptosis-related proteins, PARP, Mcl-1 and caspase-7, as assessed by western blot analysis. Numbers below the western blots represent the relative quantification of each band normalized to the loading control.

activity, the MCF-7 cells were treated with $10 \mu \mathrm{M}$ HS-146 and the expression of p-Akt was assessed by fluorescence staining. The expression of p-Akt was markedly decreased by HS-146 as compared with the untreated controls (Fig. 6B). Furthermore, to verify whether the growth inhibitory effects of HS-146 are associated with the suppression of Akt, the cells were pre-treated with $5 \mu \mathrm{M} \mathrm{SC79} \mathrm{(a} \mathrm{selective} \mathrm{Akt} \mathrm{activator)}$ for $1 \mathrm{~h}$ and then treated with $10 \mu \mathrm{M}$ HS-146 for $24 \mathrm{~h}$. After staining with MTT or rhodamine 123 (a mitochondrial dye), the cell viabilities and mitochondrial membrane potentials were analyzed, respectively. As expected, SC79 significantly reversed the reduction in cell viability and the loss of mitochondrial membrane potential induced by HS-146 treatment (Fig. 6C and D). Collectively, these results suggest that the inhibition of PI3K/Akt/mTOR signaling by HS-146 in MCF-7 cells is associated with the induction of apoptosis and the inhibition of proliferation.

HS-146 inhibits breast cancer cell metastatic ability. The ability to inhibit metastasis is a crucial aspect of breast cancer treatment. Thus, to investigate whether HS-146 has the potential to inhibit metastasis, MCF-7 cells were treated 

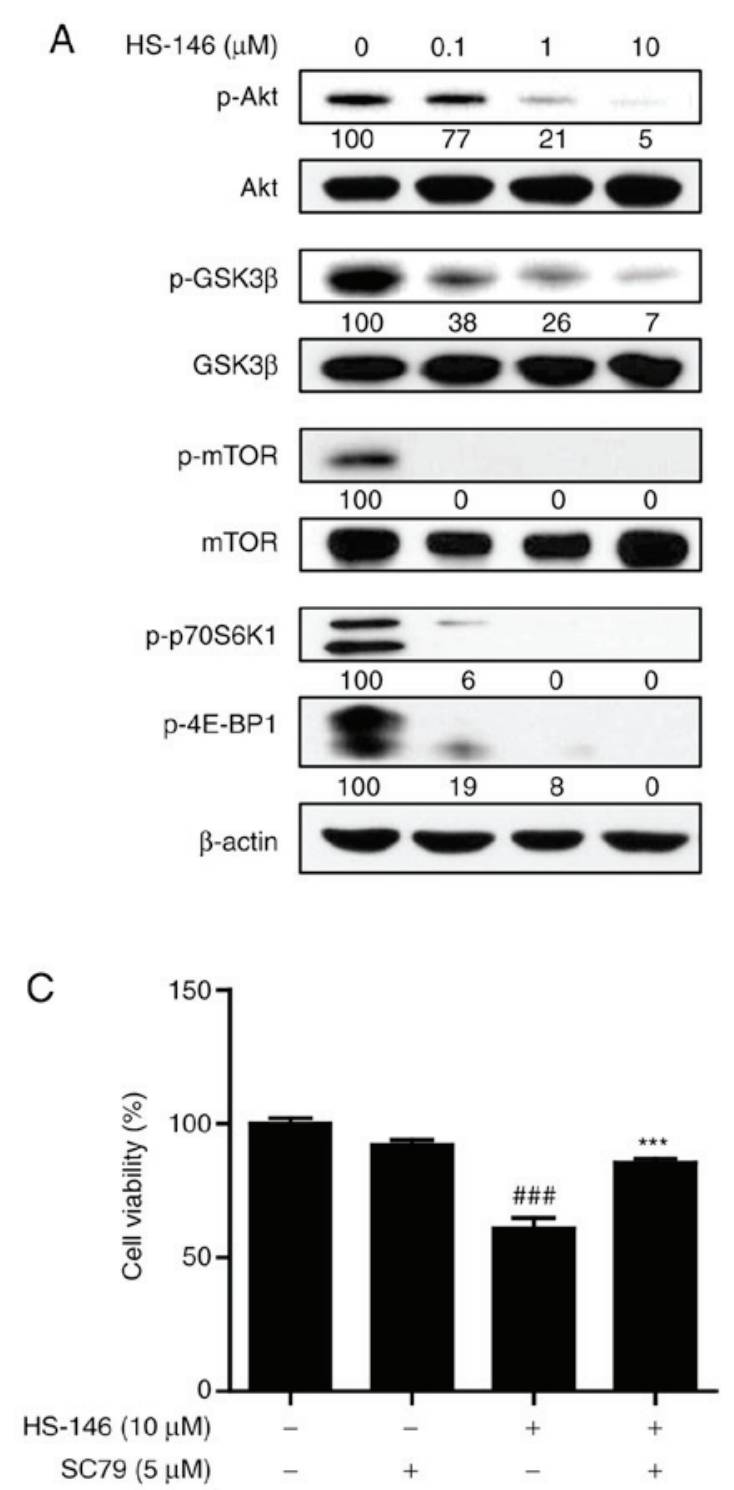

B
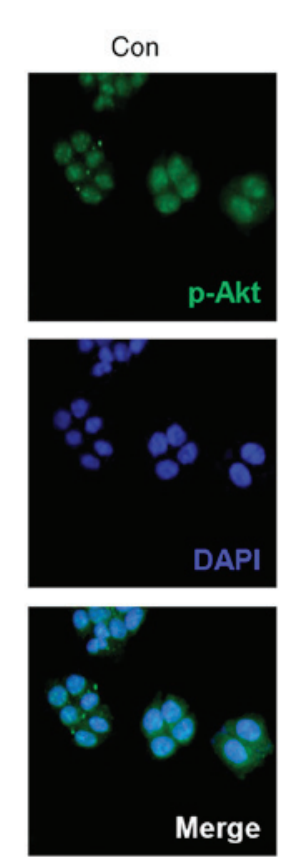

HS-146

$(10 \mu \mathrm{M})$
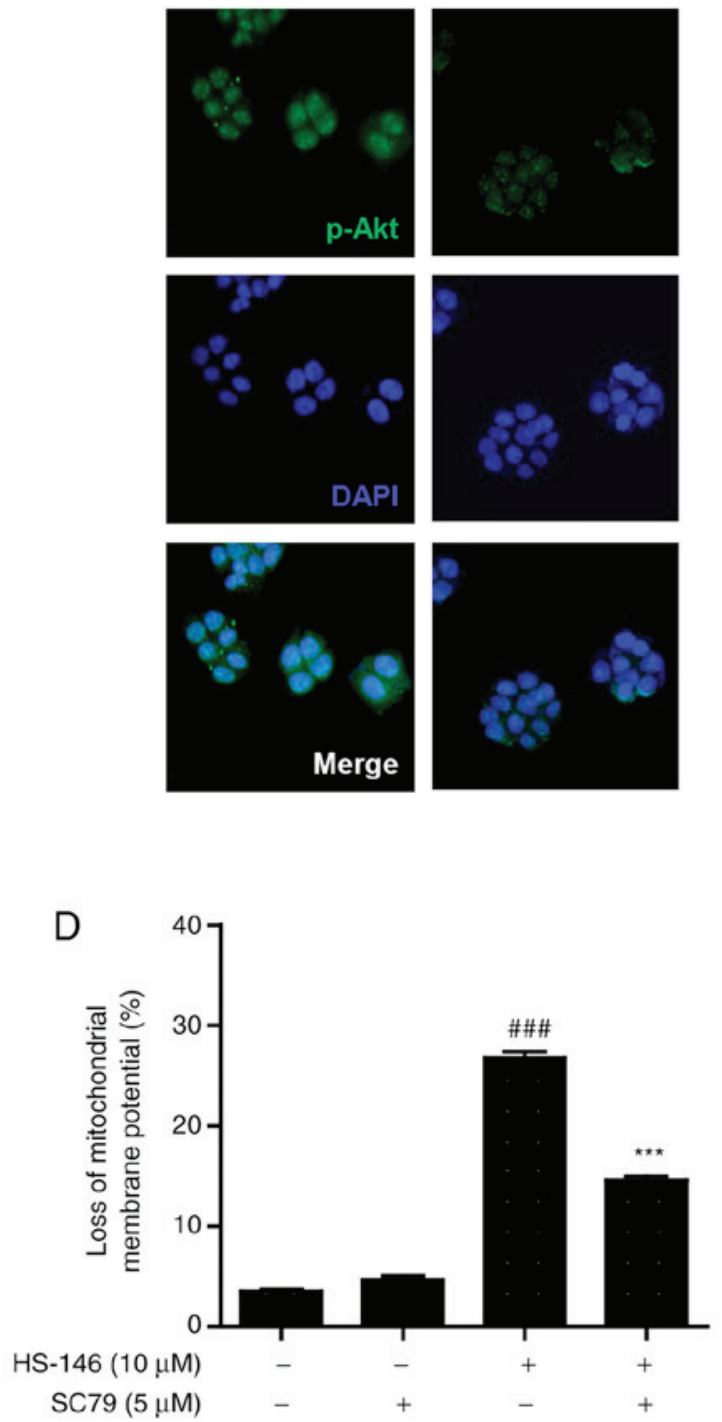

Figure 6. Effects of HS-146 on the PI3K/Akt/mTOR signaling pathway. (A) MCF-7 cells were treated with HS-146 (0-10 $\mu$ M) for $6 \mathrm{~h}$, and the protein levels of p-Akt, Akt, p-mTOR, mTOR, p-GSK3 $\beta$, GSK3 $\beta$, p-p70S6K1 and p-4E-BP1 were assessed by western blot analysis. Numbers below the western blots represent the relative quantification of each band normalized to the loading control (or total protein). (B) Cells were treated with $10 \mu \mathrm{M}$ HS-146 for $6 \mathrm{~h}$. Akt phosphorylation was detected by fluorescence microscopy (magnification, x200). Cell nuclei were stained with DAPI. (C) Inhibition of the effects of HS-146 on viability of MCF-7 cells by SC79, an Akt activator. (D) Inhibition of the effects of HS-146 on mitochondrial membrane potential of MCF-7 cells by SC79. Results are presented as the means $\pm \mathrm{SD}$. ${ }^{\# \# \#} \mathrm{P}<0.001$ vs. vehicle-treated control; ${ }^{* * *} \mathrm{P}<0.001$ vs. HS-146 treatment.

with various concentrations of HS-146 $(0.1,1$, or $10 \mu \mathrm{M})$ under hypoxic conditions induced by treatment of the cells with $100 \mu \mathrm{M} \mathrm{CoCl}_{2}$ for $24 \mathrm{~h}$. As shown in Fig. 7A, HIF-1 $\alpha$ expression was increased under hypoxic conditions in the untreated controls, and HS-146 inhibited this upregulation of HIF-1 $\alpha$ and phosphorylated Akt expression in a concentration-dependent manner. The effects of HS-146 on the expression of VEGF (an immediate downstream target of HIF-1 $\alpha$ ) were also examined by ELISA and western blot analysis. Both techniques revealed that VEGF expression was increased by hypoxia and that HS-146 inhibited this increase in a concentration-dependent manner (Fig. 7A and B).

In addition, the effects of HS-146 on the migratory and invasive activities of the MCF-7 cells were examined by a wound healing and Transwell invasion assay. Treatment of the cells with HS-146 inhibited MCF-7 cell migration in the wound healing assay in a concentration-dependent manner, and cytotoxicity was observed at the concentration of $10 \mu \mathrm{M}$ due to the serum-free conditions (Fig. 7C). Furthermore, Transwell invasion assays revealed that HS-146 reduced the invading cell numbers in a concentration-dependent manner (Fig. 7D). To investigate mechanisms responsible for the inhibitory effects of HS-146 on VEGF-induced cell migration and invasion, the expression levels of epithelial-mesenchymal transition (EMT)-related molecules, such as vimentin and E-cadherin, were examined by western blot analysis. The results revealed that HS-146 treatment decreased the level of vimentin, while it increased the level of E-cadherin in a concentration-dependent manner (Fig. 7E). 
A

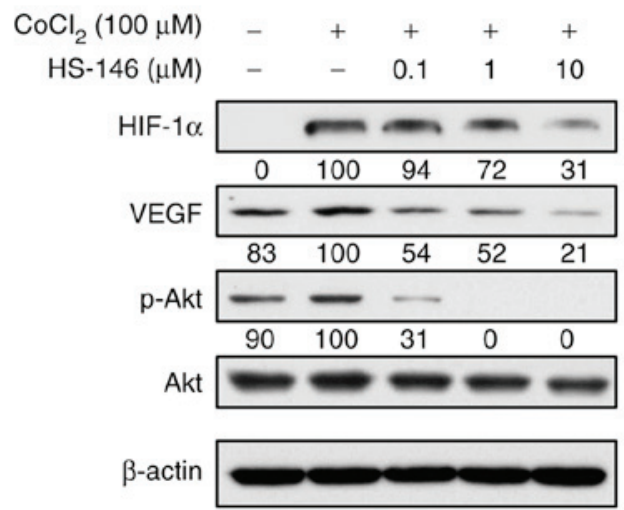

C

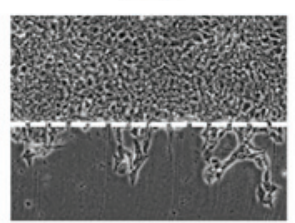

0.1

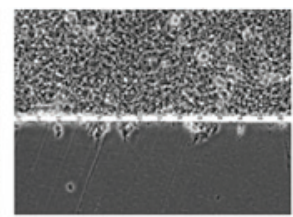

D
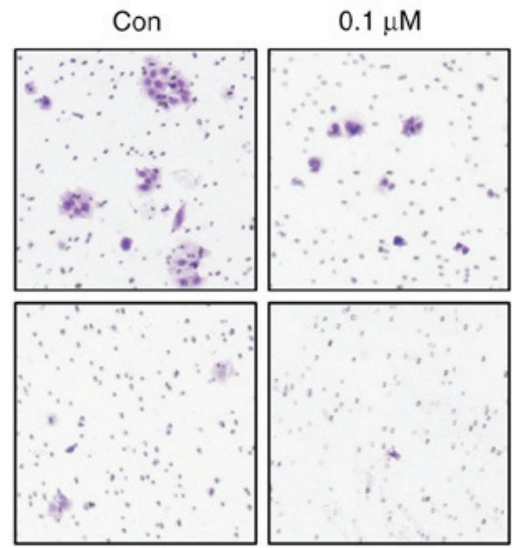

$1 \mu \mathrm{M}$

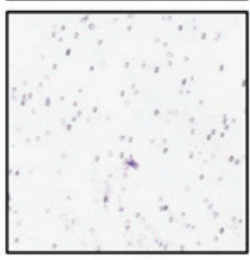

$10 \mu \mathrm{M}$

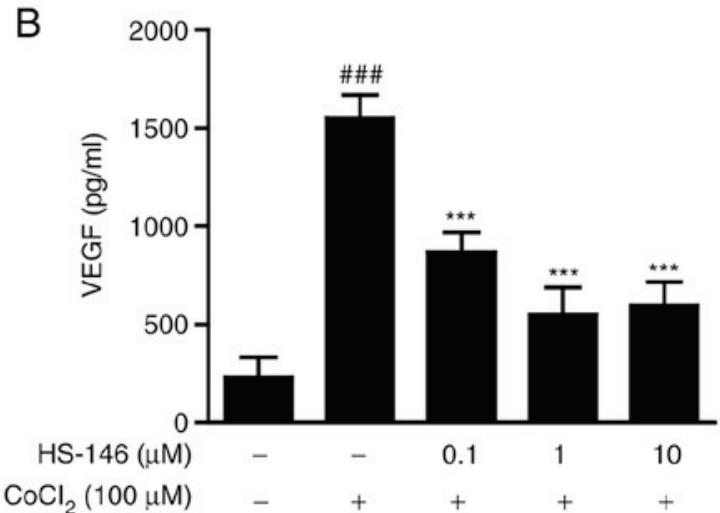

1
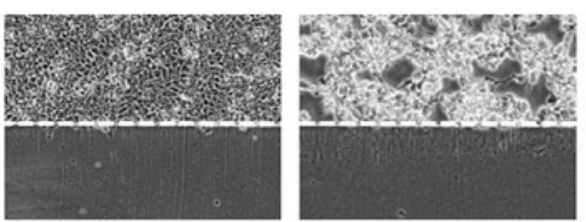

$\mathrm{E}$
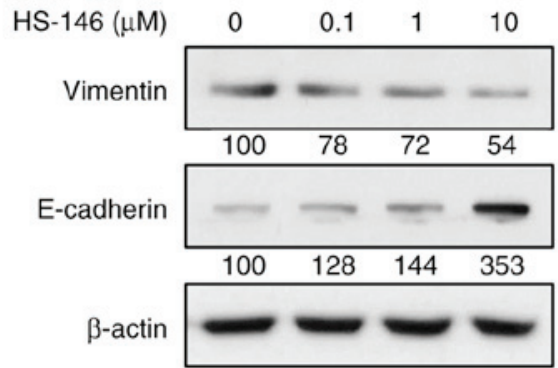

Figure 7. Effects of HS-146 on the metastatic ability of MCF-7 cells. (A) Induction of HIF-1 $\alpha$ protein by HS-146 in MCF-7 cells under hypoxic conditions (induced by $\left.\mathrm{CoCl}_{2}, 100 \mu \mathrm{M}\right)$. The expression levels of HIF-1 $\alpha$, VEGF, p-Akt, and Akt were detected by western blot analysis. (B) Effects of HS-146 (0-10 $\mu \mathrm{M}$ ) on VEGF secretion in MCF-7 cells under hypoxic conditions were determined using a VEGF ELISA kit. Results are presented as the means \pm SD. ${ }^{\# \# \# ~}<0.001$ vs. vehicle-treated control; ${ }^{* * *} \mathrm{P}<0.001$ vs. $\mathrm{CoCl}_{2}$ treatment. (C) After cell layers were scratched with a razor blade, cells were treated with $\mathrm{HS}-146(0-10 \mu \mathrm{M})$ and cell migration was monitored by microscopy. (D) The upper chambers of Matrigel-coated Transwells were treated with the vehicle or HS-146 (0.1-10 $\mu \mathrm{M})$ for $48 \mathrm{~h}$. Membranes were stained with crystal violet and observed under a microscope. (E) The expression levels of the cell migration and invasion related biomarkers, vimentin and E-cadherin, were assayed by western blot analysis. Numbers below the western blots represent the relative quantification of each band normalized to the loading control (or total protein).

\section{Discussion}

A number of research groups continue to identify novel strategies for the treatment of cancer. Over the past two decades, one of the most promising novel therapies involves treatments based on small molecule inhibitors that target substances critical for the development and progression of cancer. Developed small molecule inhibitors for the treatment of breast cancer include Cdk4/6 inhibitors (palbociclib, ribociclib and abemaciclib), PARP inhibitors (olaparib, veliparib and talazoparib) and PI3K inhibitors (buparlisib and alpelisib) (19). Some of these inhibitors have been approved by the FDA for the treatment of breast cancer or have progressed to late-stage clinical trials $(19,20)$ (https://clinicaltrials gov/ct $2 /$ show $/$ NCT03820830?term $=$ NCT03820830\&draw $=$ 2\&rank=1, https://clinicaltrials.gov/ct2/show/NCT03286842 ?term $=$ NCT03286842 \&draw $=2 \&$ rank=1, https://clinicaltrials.gov/ct2/show/NCT01945775?term=NCT01945775\&draw $=2 \& \mathrm{rank}=1$ ). The PI3K/Akt/mTOR signaling pathway is one of the most frequently dysregulated pathways in human cancer and the activation of this pathway has been estimated to occur in as many as $70 \%$ of breast cancer cases (20-23). Activating mutations in PIK3CA have been shown to drive the initiation and progression of breast cancer, and thus, the selective inhibition of $\mathrm{PI} 3 \mathrm{~K} \alpha$ is viewed as an important therapeutic strategy (24). Recently, several investigators have reported that PIK3CA mutation is significantly associated with estrogen receptor (ER)-positive breast cancer (25-27).

In the present in vitro study, it was found that HS-146 (a novel PI3K $\alpha$ inhibitor) exerts anticancer effects and that the underlying mechanisms of its effects are associated with the regulation of the PI3K/Akt/mTOR pathway, and the consequent 
suppression of cancer cell proliferation by cell cycle arrest, increased apoptosis and the inhibition of metastasis. The effects of potential anticancer agents are often determined by investigating their effects on the proliferation, apoptosis and the induction of cancer cell cycle arrest $(28,29)$. Therefore, the present study first investigated the ability of HS-146 to suppress the proliferation of 4 different breast cancer cell lines, namely the MCF-7 $\left(\mathrm{ER}^{+} / \mathrm{PR}^{+}\right), \mathrm{BT}-474\left(\mathrm{ER}^{+} / \mathrm{PR}^{+} / \mathrm{HER} 2^{+}\right)$, SKBR3 $\left(\right.$ HER $2^{+}$) and MDA-MB-231 (triple-negative) breast cancer cell lines. HS-146 was found to inhibit the proliferation of all 4 cell lines and to most effectively inhibit that of MCF-7 cells. It was also found that ER-positive cells (MCF-7 and BT-474) were more sensitive to HS-146 compared with ER-negative cells (SKBR3 and MDA-MB-231).

Cancer development is a result of a number of cellular events, one of which is the abnormal regulation of the cell cycle (30). Cyclin D1 positively regulates the transition from the G1 phase to the $\mathrm{S}$ phase, and the Cdk inhibitor, $\mathrm{p} 21^{\text {Wafl/Cip1 }}$, negatively regulates cell cycle progression $(31,32)$. Since cyclin D1 overexpression has been linked to the development and progression of cancer, it is viewed as an attractive developmental target for anticancer agents, and to date, several compounds have been demonstrated to induce cyclin D1 degradation (31). The formation of complexes of cyclin D-Cdk4 and cyclin E-Cdk2 are crucial for the G1-S progression in mammalian cells and $(33,34)$. Cdk inhibitors such as $\mathrm{p} 27^{\mathrm{Kipl}}$ and $\mathrm{p} 21^{\text {Wafl/Cip1 }}$ is known to regulate negatively the activity of these complexes (35). In the present study, HS-146 increased the numbers of cells in the G0/G1 phase and upregulated the protein expression of $\mathrm{p} 21^{\text {Wafl/Cipl }}$; by contrast, it downregulated the protein expression of cyclin D1, cyclin E, Cdk2 and Cdk4. Thus, it appears that HS-146 inhibits MCF-7 proliferation by inducing G0/G1 arrest.

Apoptosis is an essential normal cellular activity and is required for tissue remodeling and for the removal of damaged or aging cells (36). The induction of apoptosis is a possible outcome of DNA damage, as has been widely reported $(28,37)$, and several studies have been performed to identify means with which to induce apoptosis $(36,38,39)$. In the present study, it was found that HS-146 induced apoptosis, as evidenced by observations of DNA fragmentation and nuclear condensation, as well as quantitative data using Annexin V-FITC/PI apoptosis assay. The anti-apoptotic $\mathrm{Bcl}-2$ family protein, $\mathrm{Mcl}-1$, is known to play an important role in breast cancer cell survival and chemoresistance (40), whereas caspase-7 is an effector of apoptosis and activated caspase-7 can cleave PARP during apoptosis (41). The present study demonstrated that HS-146 inhibited the activation of Mcl-1 and caspase-7, and increased PARP cleavage. These findings confirm that the anticancer effects of HS-146 are mediated via the intrinsic apoptotic pathway in MCF-7 cells.

The PI3K/Akt/mTOR signaling pathway has been well documented to play a major role in carcinogenesis in breast cancer cells. Activated PI3K converts PIP2 (phosphatidylinositol bisphosphate) to PIP3 (phosphatidylinositol triphosphate), which results in the phosphorylation of Akt. In addition, Akt is activated by PDK1 and mTORC2 (mTOR complex 2), of which activation regulates GSK3 $\beta$ and cyclin D1, and promotes cell cycle progression. Furthermore, Akt also activates mTORC1 (mTOR complex 1), which leads to the phosphorylation of p70S6K and 4E-BP1 $(5,6)$. Based on this mechanism, the present study evaluated the inhibitory effect of HS-146 on PI3K/Akt/mTOR signaling. The results of western blot analysis revealed that HS-146 markedly inhibited the activation (phosphorylation) of Akt, mTOR, GSK3 $\beta$, p70S6K1 and 4E-BP1. In addition, it was confirmed that Akt activation was markedly suppressed in HS-146-treated MCF-7 cells by immunofluorescence staining. It was further demonstrated that the pharmacological activation of Akt by SC79 antagonized the growth inhibitory effects of HS-146 against MCF-7 cells. Thus, the anticancer effects of HS-146 may be partly mediated via the inhibition of the Akt signaling pathway.

The activation of the PI3K/Akt pathway in tumor cells can increase the expression of HIF-1 $\alpha$ protein, which activates the transcription of VEGF promoter, a key factor of tumor angiogenesis that regulates key features, such as angiogenesis and invasion. Numerous researchers have suggested that uncontrolled angiogenesis is central to tumor growth and metastasis (42-44). Thus, the present study investigated the anti-angiogenic and anti-metastatic effects of HS-146 on MCF-7 cells. HS-146 suppressed the hypoxia-induced increase in the expression of HIF-1 $\alpha$, VEGF and p-Akt, the amount of secreted VEGF, and MCF-7 migration and invasion. EMT is known to play a central role in acquiring mesenchymal features from epithelial cells, and enhances the cell migratory and invasive potential, resulting in cancer progression $(45,46)$. Therefore, the suppressive effects of HS-146 against the migration and invasion of MCF-7 cells were further supported by western blot analysis that confirmed the inhibition of EMT by the decrease in the expression of vimentin and the increase in the expression of E-cadherin by HS-146 treatment.

In conclusion, the present study synthesized HS-146 and found that it functions as a PI3K $\alpha$ inhibitor with potent anticancer effects on human breast cancer cells. In MCF-7 cells, HS-146 effectively inhibited proliferation, induced G0/G1 cell cycle arrest and induced apoptosis by inhibiting the $\mathrm{PI} 3 \mathrm{~K} / \mathrm{Akt} / \mathrm{mTOR}$ signaling pathway. These findings suggest that HS-146 has potential for use as a therapeutic candidate for breast cancer, which offers a developmental starting point for the treatment for other human cancers.

\section{Acknowledgements}

Not applicable.

\section{Funding}

The present study was supported by the National Research Foundation of Korea (grant nos. 2018R1A2A1A05077263, 2019M3E5D1A02069621, 2014M3C1A3051476 and 2014009392) and the Institute for Basic Science (IBS-R010-A2).

\section{Availability of data and materials}

The datasets used and/or analyzed during the current study are available from the corresponding author on reasonable request.

\section{Authors' contributions}

SSH and SH (the principal director and study supervisor) were responsible for the design of the study and for obtaining 
funding. OHK, JHL and SM participated in the study design and experiments, and wrote the manuscript. SYP carried out experiments and the statistical analysis. All authors participated in the preparation of the manuscript, and read and approved the final version.

\section{Ethics approval and consent to participate}

Not applicable.

\section{Patient consent for publication}

Not applicable.

\section{Competing interests}

The authors declare that they have no competing interests.

\section{References}

1. Harbeck N and Gnant M: Breast cancer. Lancet 389: 1134-1150, 2017.

2. Pierobon M, Ramos C, Wong S, Hodge KA, Aldrich J, Byron S, Anthony SP, Robert NJ, Northfelt DW, Jahanzeb M, et al: Enrichment of PI3K-AKT-mTOR pathway activation in hepatic metastases from breast cancer. Clin Cancer Res 23: 4919-4928, 2017.

3. Peng Y, Wang Y, Tang N, Sun D, Lan Y, Yu Z, Zhao X, Feng L, Zhang B, Jin L, et al: Andrographolide inhibits breast cancer through suppressing COX-2 expression and angiogenesis via inactivation of p300 signaling and VEGF pathway. J Exp Clin Cancer Res 37: 248, 2018.

4. Cai F, Zhang L, Xiao X, Duan C, Huang Q, Fan C, Li J, Liu X, Li S and Liu Y: Cucurbitacin B reverses multidrug resistance by targeting CIP2A to reactivate protein phosphatase $2 \mathrm{~A}$ in MCF-7/adriamycin cells. Oncol Rep 36: 1180-1186, 2016.

5. Li GY, Jung KH, Lee H, Son MK, Seo J, Hong SW, Jeong Y, Hong S and Hong SS: A novel imidazopyridine derivative, HS-106, induces apoptosis of breast cancer cells and represses angiogenesis by targeting the $\mathrm{PI} 3 \mathrm{~K} / \mathrm{mTOR}$ pathway. Cancer Lett 329: 59-67, 2013.

6. Popolo A, Pinto A, Daglia M, Nabavi SF, Farooqi AA and Rastrelli L: Two likely targets for the anti-cancer effect of indole derivatives from cruciferous vegetables: PI3K/Akt/mTOR signalling pathway and the aryl hydrocarbon receptor. Semin Cancer Biol 46: 132-137, 2017.

7. Miller TW, Rexer BN, Garrett JT and Arteaga CL: Mutations in the phosphatidylinositol 3-kinase pathway: Role in tumor progression and therapeutic implications in breast cancer. Breast Cancer Res 13: 224, 2011.

8. Qin H, Liu L, Sun S, Zhang D, Sheng J, Li B and Yang W: The impact of PI3K inhibitors on breast cancer cell and its tumor microenvironment. PeerJ 6: e5092, 2018.

9. Xing Y, Lin NU, Maurer MA, Chen H, Mahvash A, Sahin A, Akcakanat A, Li Y, Abramson V, Litton J, et al: Phase II trial of AKT inhibitor MK-2206 in patients with advanced breast cancer who have tumors with PIK3CA or AKT mutations, and/or PTEN loss/PTEN mutation. Breast Cancer Res 21: 78, 2019.

10. Frustaci AM, Tedeschi A, Deodato M, Zamprogna G, Cairoli R and Montillo M: Duvelisib: A new phosphoinositide-3-kinase inhibitor in chronic lymphocytic leukemia. Future Oncol 15: 2227-2239, 2019

11. Massacesi C, Di Tomaso E, Urban P, Germa C, Quadt C, Trandafir L, Aimone P, Fretault N, Dharan B, Tavorath R and Hirawat S: PI3K inhibitors as new cancer therapeutics: Implications for clinical trial design. Onco Targets Ther 9: 203-210, 2016

12. Bendell JC, Varghese AM, Hyman DM, Bauer TM, Pant S, Callies S, Lin J, Martinez R, Wickremsinhe E, Fink A, et al: A first-in-human phase 1 study of LY3023414, an oral PI3K/mTOR dual inhibitor, in patients with advanced cancer. Clin Cancer Res 24: 3253-3262, 2018.
13. Lin T, Leung C, Nguyen KT and Figlin RA: Mammalian target of rapamycin (mTOR) inhibitors in solid tumours. Clin Pharm 8, 2016.

14. Markham A: Alpelisib: First global approval. Drugs 79: 1249-1253, 2019.

15. Kim O, Jeong Y, Lee H, Hong SS and Hong S: Design and synthesis of imidazopyridine analogues as inhibitors of phosphoinositide 3-kinase signaling and angiogenesis. J Med Chem 54: 2455-2466, 2011.

16. Yang H, Medeiros PF, Raha K, Elkins P, Lind KE, Lehr R, Adams ND, Burgess JL, Schmidt SJ, Knight SD, et al: Discovery of a potent class of PI3K $\alpha$ inhibitors with unique binding mode via encoded library technology (ELT). ACS Med Chem Lett 6: 531-536, 2015.

17. John RR, Malathi N, Ravindran $C$ and Anandan S: Mini review: Multifaceted role played by cyclin D1 in tumor behavior. Indian J Dent Res 28: 187-192, 2017.

18. Liu S, Bishop WR and Liu M: Differential effects of cell cycle regulatory protein $\mathrm{p} 21$ (WAF1/Cip1) on apoptosis and sensitivity to cancer chemotherapy. Drug Resist Updat 6: 183-195, 2003.

19. Nur Husna SM, Tan HT, Mohamud R, Dyhl-Polk A and Wong KK: Inhibitors targeting CDK4/6, PARP and PI3K in breast cancer: A review. Ther Adv Med Oncol 10: 1758835918808509, 2018.

20. Lee JJ, Loh K and Yap YS: PI3K/Akt/mTOR inhibitors in breast cancer. Cancer Biol Med 12: 342-354, 2015.

21. Castaneda CA, Cortes-Funes H, Gomez HL and Ciruelos EM: The phosphatidyl inositol 3-kinase/AKT signaling pathway in breast cancer. Cancer Metastasis Rev 29: 751-759, 2010.

22. Fruman DA, Chiu H, Hopkins BD, Bagrodia S, Cantley LC and Abraham RT: The PI3K pathway in human disease. Cell 170: 605-635, 2017.

23. Janku F, Yap TA and Meric-Bernstam F: Targeting the PI3K pathway in cancer: Are we making headway? Nat Rev Clin Oncol 15: 273-291, 2018.

24. Liu XL, Xu YC, Wang YX, Chen Y, Wang BB, Wang Y, Chen YH, Tan C, Hu LD, Ma QY, et al: Decrease in phosphorylated ERK indicates the therapeutic efficacy of a clinical PI3K $\alpha$-selective inhibitor CYH33 in breast cancer. Cancer Lett 433: 273-282, 2018.

25. Sabine VS, Crozier C, Brookes CL, Drake C, Piper T, van de Velde CJ, Hasenburg A, Kieback DG, Markopoulos C, Dirix L, et al: Mutational analysis of PI3K/AKT signaling pathway in tamoxifen exemestane adjuvant multinational pathology study. J Clin Oncol 32: 2951-2958, 2014.

26. Zardavas D, Marvelde LT, Milne R, Joensuu H, Moynahan ME, Hennessy B, Bieche I, Saal LH, Stal O, Iacopetta B, et al: Tumor PIK3CA genotype and prognosis: A pooled analysis of 4,241 patients (pts) with early-stage breast cancer (BC). J Clin Oncol 33 (Suppl. 15): S516, 2015.

27. Yang SX, Polley E and Lipkowitz S: New insights on PI3K/AKT pathway alterations and clinical outcomes in breast cancer. Cancer Treat Rev 45: 87-96, 2016.

28. Dhatchana Moorthy N, Muthu Ramalingam B, Iqbal S, Mohanakrishnan AK, Gunasekaran K and Vellaichamy E: Novel isothiacalothrixin B analogues exhibit cytotoxic activity on human colon cancer cells in vitro by inducing irreversible DNA damage. PLoS One 13: e0202903, 2018.

29. Lee JH, Lee H, Yun SM, Jung KH, Jeong Y, Yan HH, Hong S and Hong SS: IPD-196, a novel phosphatidylinositol 3-kinase inhibitor with potent anticancer activity against hepatocellular carcinoma. Cancer Lett 329: 99-108, 2013.

30. Vermeulen K, Van Bockstaele DR and Berneman ZN: The cell cycle: A review of regulation, deregulation and therapeutic targets in cancer. Cell Prolif 36: 131-149, 2003.

31. Alao JP: The regulation of cyclin D1 degradation: Roles in cancer development and the potential for therapeutic invention. Mol Cancer 6: 24, 2007

32. Deng T, Yan G, Song X, Xie L, Zhou Y, Li J, Hu X, Li Z, Hu J, Zhang Y, et al: Deubiquitylation and stabilization of p21 by USP11 is critical for cell-cycle progression and DNA damage responses. Proc Natl Acad Sci USA 115: 4678-4683, 2018.

33. Morgan DO: Principles of CDK regulation. Nature 374: 131-134, 1995.

34. Reed SI, Bailly E, Dulic V, Hengst L, Resnitzky D and Slingerland J: G1 control in mammalian cells. J Cell Sci Suppl 18: 69-73, 1994.

35. Sherr CJ and Roberts JM: CDK inhibitors: Positive and negative regulators of G1-phase progression. Genes Dev 13: 1501-1512, 1999. 
36. Lim JH, Lee YM, Park SR, Kim DH and Lim BO: Anticancer activity of hispidin via reactive oxygen species-mediated apoptosis in colon cancer cells. Anticancer Res 34: 4087-4093, 2014.

37. Norbury CJ and Zhivotovsky B: DNA damage-induced apoptosis. Oncogene 23: 2797-2808, 2004

38. Yang L, Liu Y, Wang M, Qian Y, Dai X, Zhu Y, Chen J, Guo S and Hisamitsu T: Celastrus orbiculatus extract triggers apoptosis and autophagy via PI3K/Akt/mTOR inhibition in human colorectal cancer cells. Oncol Lett 12: 3771-3778, 2016.

39. Kumar D, Das B, Sen R, Kundu P, Manna A, Sarkar A, Chowdhury C, Chatterjee M and Das P: Andrographolide analogue induces apoptosis and autophagy mediated cell death in U937 cells by inhibition of PI3K/Akt/mTOR pathway. PLoS One 10: e0139657, 2015.

40. Basu A and Sridharan S: Regulation of anti-apoptotic Bcl-2 family protein Mcl-1 by S6 kinase 2. PLoS One 12: e0173854, 2017.

41. Walsh JG, Cullen SP, Sheridan C, Luthi AU, Gerner C and Martin SJ: Executioner caspase-3 and caspase-7 are functionally distinct proteases. Proc Natl Acad Sci USA 105: 12815-12819, 2008.
42. Karar J and Maity A: PI3K/AKT/mTOR pathway in angiogenesis. Front Mol Neurosci 4: 51, 2011.

43. Choi MJ, Lee H, Lee JH, Jung KH, Kim D, Hong S and Hong SS: The effect of HS-111, a novel thiazolamine derivative, on apoptosis and angiogenesis of hepatocellular carcinoma cells. Arch Pharm Res 35: 747-754, 2012

44. Kim YW, Jang EJ, Kim CH and Lee JH: Sauchinone exerts anticancer effects by targeting AMPK signaling in hepatocellular carcinoma cells. Chem Biol Interact 261: 108-117, 2017.

45. Thiery JP and Sleeman JP: Complex networks orchestrate epithelial-mesenchymal transitions. Nat Rev Mol Cell Biol 7: 131-142, 2006.

46. Singh S and Chakrabarti R: Consequences of EMT-driven changes in the immune microenvironment of breast cancer and therapeutic response of cancer cells. J Clin Med 8 pii: E642, 2019. 